\title{
An information privacy culture instrument to measure consumer privacy expectations and confidence
}

\author{
Adéle da Veiga \\ College of Science, Engineering and Technology, School of Computing, University of South Africa, P.O. \\ Box 392, UNISA 0003, South Africa \\ dveiga@unisa.ac.za
}

\begin{abstract}
Purpose - This research proposes an information privacy culture index framework (IPCIF) with a validated information privacy culture index instrument (IPCII) to measure information privacy culture across nations. The framework is based on consumers' privacy expectations, their actual experiences when organisations process their personal information, as well as their general privacy concerns.

Design/methodology/approach - A survey method was deployed to collect data in South Africa - the first participating country in the study - to start building a global information privacy culture index and to validate the questionnaire.

Findings - The information privacy culture index revealed that there seems to be a disconnect between what consumers expect in terms of privacy and the way in which organisations are honouring (or failing to honour) those expectations, which results in a breach of trust and the social contract being violated.

Practical implications - Governments, information regulators and organisations can leverage the results of the privacy culture index to implement corrective actions and controls aimed at addressing the gaps identified from a consumer and compliance perspective. The validated IPCII can be used by both academia and industry to measure the information privacy culture of an institution, organisation or country to identify what to improve in order to address consumer privacy expectations and concerns.

Originality/value - The IPCIF and validated IPCII is the first tool that combines the concepts of consumer expectations and their confidence levels in whether organisations are meeting their privacy expectations, which are in line with the Fair Information Practice Principles (FIPPs) and the privacy guidelines of the Organisation for Economic Cooperation and Development (OECD), in order to determine gaps and define improvement plans.
\end{abstract}

Keywords - culture, data privacy, data protection, information privacy, framework, index, consumer, perceptions, questionnaire, OECD, FIPPs, POPIA

Paper type - Research paper

\section{Introduction}

Privacy is a fundamental human right with some of the first privacy legislation dating back to the fourteenth century (Swire and Ahmad 2012). Today, privacy is regulated in over a hundred countries with most privacy laws based on international privacy principles (DLA Piper 2018; Greenleaf 2014; Bellman et al. 2004). While privacy is regulated from a common set of principles, people in different countries or from different cultures have different privacy expectations (Moore 2008; Kemp and Moore 2007). Various studies have been conducted into privacy and the concerns that consumers and nations have about the concept (Smith et al. 1995; Bellman et al. 2004; Malhotra et al. 2004; Dell EMC 2015; Symantec 2015; Deloitte \& Touche 2017). Privacy expectations as well as privacy concerns vary between nations and within the demographic groups that make up a nation. At the same time, the maturity of privacy or data protection regulations vary between jurisdictions, with certain jurisdictions having a "heavy" stance towards the implementation and regulation thereof, while others are perceived as "moderate" or "low" (DLA Piper 2018). 
Additional insight can be obtained by comparing the privacy expectations of consumers or nations to their actual experiences when organisations process their personal information. This would allow for the identification of gaps, which would help improve the safeguarding of personal information and build a trusting relationship. It would also be beneficial if the privacy concepts measured in this way were aligned with best practice principles of privacy, such as those proposed in the Fair Information Practice Principles (FIPPs) (FIPP 2018) and the Guidelines on the Protection of Personal Information and Transborder Flows of Personal Data of the Organisation for Economic Cooperation and Development (OECD 2013), to allow for comparisons between countries.

This research study aims to develop a global information privacy culture index (IPCI), whereby consumers' or nations' expectations of how organisations should deal with their personal information, can be compared to their actual experiences in this respect. The paper begins by defining the concept of information privacy culture, after which the information privacy culture index framework (IPCIF) and instrument (IPCII) are discussed. This is followed by a discussion of a survey conducted in South Africa - as the first country to participate in the study - followed by the validity and reliability results of the instrument. The discussion of the results is followed by the conclusion, after which the complete IPCII questionnaire is provided.

\section{Information privacy culture}

The definition of information security culture has been extended to incorporate the concept of privacy, referred to as "information protection culture". This is defined as

"a culture in which the protection of information and upholding of privacy are part of the way things are done in an organisation. It is a culture in which employees illustrate attitudes, assumptions, beliefs, values and knowledge that contribute to the protection and privacy of information when processing it at any point in time in the information life cycle, resulting in ethical and compliant behaviour" (Da Veiga and Martins 2015: 249)

This definition focuses on the organisational context, which incorporates the perspectives of employees. Similarly, the privacy culture definition of the Information Systems Audit and Control Association (ISACA) also relates to a culture in an organisational context. ISACA (2016) refers to a privacy culture as one that adopts privacy protection behaviours, such as ethical behaviour and proactive privacy commination. The privacy culture may vary in maturity across organisations. There may be no strategic focus or formal documentation, but on the other hand the privacy culture may be mature in guiding employee behaviour when they process personal information. ISACA argues that organisations should extend their privacy focus to "move beyond simply considering legal compliance requirements for privacy by implementing a culture of ethical privacy protection activities" (ISACA 2016:71).

The implication of moving towards a privacy culture entails that employees should ultimately display a pattern of behaviour of upholding the privacy of customer information at all times. The organisation may have a view of how its employees interact with consumer data, while consumers may have a different experience when the organisation processes their personal information. This view is, however, not included in the above privacy culture definitions.

When considering the consumer's view in the perception towards a privacy culture one needs to reflect on a national culture. The Business Dictionary (2018) defines a national culture as "[t]he set of norms, behaviors, beliefs and customs that exist within the population of a sovereign nation. International organisations develop management and other practices in accordance with the national culture they are operating in." This relates to the research by Hofstede et al. (2010), which focuses on the influence national culture has on workplace values, where the norms, behaviours, beliefs and customs of a nation affect the practices in an organisation and become part of the organisational culture.

In the context of this study, information privacy culture relates to the perceptions and beliefs a nation (hereafter "consumer") has about the processing of (their) citizens' personal information - what expectations they have and how they believe organisations are meeting those expectations given certain information privacy principles (or requirements). The study therefore encapsulates "how things should be done" and "how things are perceived to be done", in relation to privacy. 


\section{Data privacy perception instruments}

There have been attempts to develop instruments to measure consumers' perceptions as they pertain specifically to privacy. The Concern for Information Privacy (CFIP) instrument, developed by Smith et al. (1995), incorporates one factor that focuses on information collection, unauthorised secondary use, improper access and errors. This instrument has been expanded to incorporate internet user concerns that address three dimensions, namely collection, control and awareness from a social contract perspective (Bellman et al. 2004; Malhotra 2004). A social contract is established between consumers and the organisation when the former provide their personal information to the latter, and they have the option to decide how that information is to be used (Phelps, Nowak and Ferrell 2000). A breach of this social contract occurs when the organisation, for example, shares the consumers' personal information with third parties, without being granted consent.

Consumers' expectations about the way in which organisations use and protect their personal information may differ. The Westin Privacy Segmentation Index segments consumers into three categories (Kumaraguru and Cranor 2005; Miltgen 2009):

- Privacy fundamentalists. Members of this group are mainly concerned about sharing and safeguarding their personal information.

- Privacy pragmatists. They tend to seek a balance between the advantages and disadvantages of sharing private information, before arriving at a decision.

- Privacy unconcerned. These people believe there is greater benefit to be derived from sharing their personal information, and they are thus least protective of their privacy (adapted from Woodruff et al. 2014).

Privacy fundamentalists may be highly concerned if an organisation were to share their personal information with third parties, whereas the privacy unconcerned group may see value in such sharing. These divergent views thus have different effects on the social contract and the trusting relationship the consumer has formed with the organisation. If the social contract is breached, it could result in noncompliance with data protection legislation.

The work of Morton and Sasse (2014) segments consumers (users) into five categories with regard to their privacy concerns and the use of technology: information controllers (seeking to control their personal information collection, use and sharing); security concerned (expecting security of personal information); benefit seekers (valuing the benefits in return for providing personal information); crowd followers (relying on advice from family or friends); and organisational assurance seekers (requiring assurance for processing of information like a privacy policy). The aforementioned research and the Westin Privacy Segmentation Index indicate that consumers have different privacy concerns and expectations from organisations that process their personal information. If they feel that the organisation does not meet their expectations, "they may respond emotionally and reject it, or distrust the motives of the providing organisation" (Morton and Sasse 2014:102).

While consumers may have diverse expectations about the use and protection of their personal information, organisations must comply with the minimum data protection regulations of those jurisdictions that apply to them. If one considers the Western Privacy Index categories, some consumers may have expectations that are in line with data protection regulatory requirements (e.g. privacy fundamentalists), while other groups (e.g. privacy unconcerned) may have lower expectations. By contrast, organisations' compliance with regulatory requirements could vary leading to a range of fines being imposed on them for non-compliance (Australian Government 2018; ICO 2017). While organisations have an obligation to their customers, they must also comply with data protection legislation when processing personal information, irrespective of the consumers' expectations. The FIPPs (FIPP 2018) and the guidelines of the OECD (2013) cover eight fundamental principles for data protection: accountability, processing or use limitation, collection limitation, purpose specification, information quality, openness, security safeguards, data subject participation and access - all of which have been incorporated into most data protection regulations (Bellman et al. 2004).

Industry-related privacy perception instruments are available, such as those developed by Dell EMC (2015), Symantec (2015) and KPMG (2016), which focus on general privacy and online consumer concerns. The Data Protection Eurobarometer (European Commission 2015; European Commission 2016) 
is commissioned by the European Commission's Directorate-General for Communications Networks, Content and Technology (DG CONNECT) and is conducted across the 28 European Member states. These surveys cover aspects such as consumers' perception towards providing personal information and online profiling, concerns about privacy and levels of privacy awareness in an online context. Deloitte and Touche in Australia (2017) conducted a privacy index survey of organisational perspectives about privacy in a work context. The TRUSTe/National Cyber Security Alliance (NCSA 2016) Consumer Privacy Index focuses on consumer concerns, privacy awareness and business impact in the online context. The Dell EMC (2015) Privacy Index is a global survey aimed at measuring consumers' perceptions of the online privacy they enjoy. It includes a ranking across countries, which indicates the willingness of consumers to share private information for the sake of greater convenience. The factors measured are not inclusive of the OECD privacy principles, but survey respondents' views on privacy and awareness in an online context or in respect of organisational privacy measures that have been implemented. These instruments neither incorporate a perspective on consumer expectations, nor do they determine whether organisations are meeting those expectations in line with FIPPs. While Smith's (2014) CFIP measures consumer expectations, it does not gauge perceptions of whether organisations are meeting those expectations; it also does not incorporate all the FIPPs or data protection guidelines outlined by the OECD.

The author therefore proposes that both concepts - consumer expectations and perceptions of whether organisations are meeting those expectations - should be considered in an effort to determine the IPCI of a nation and its diverse demographic groups. Expectations and beliefs regarding compliance should be aligned with the FIPPs and OECD privacy guidelines to ensure that regulatory requirements form the cornerstone of the culture being measured, as that would aid in comparing indices across nations.

\section{The information privacy culture index framework (IPCIF)}

The information privacy culture index framework (IPCIF) is portrayed in figure 1 as outlined in Da Veiga (2017). The components are as follows:

- Regulatory factor requirements. The principles of the FIPPs and OECD privacy guidelines were summarised in eight regulatory factors, each with a number of requirements. Three more regulatory factors were added, namely unsolicited marketing, cross-border transfers and sensitive personal information (PI). These factors are in line with developments in Europe with regard to the General Data Protection Regulation (GDPR) (European Parliament and Council 2016) and other data protection legislation that covers these concepts, such as the Protection of Personal Information Act (POPIA) (Republic of South Africa 2013) of South Africa, the Data Protection Act (DPA) of the United Kingdom (Great Britain 1998) and Australia's Privacy Act (Australia Government 1988). The requirements of these regulatory factors serve as the minimum data protection requirements in the proposed framework and form the cornerstone of the framework. The regulatory requirements of a specific country can be mapped to the regulatory factor requirements in the IPCIF for comparison purposes.

- Privacy expectations. This block represents consumers' expectations about each of the regulatory factor requirements. The aim is to establish what consumers' expectations are for each of the requirements of the 11 regulatory factors. Although the regulatory factor requirements serve as a minimum baseline based on the OECD and FIPPS, consumers may have a lower or higher expectation for certain regulatory factor requirements. This could give an indication as to the privacy culture of a country.

- Compliance/meeting expectations. The compliance/meeting expectations block depicts the perceptions of consumers as to whether organisations are meeting the requirements of each of the 11 regulatory factors, thus consumers' confidence in whether organisations' behaviour is in line with the regulatory factor requirements. While the regulatory factor requirements entail the minimum requirements for data privacy, one would expect organisations in jurisdictions with enacted data privacy laws to comply with those requirements and that consumers experience it as such. Where consumers believe organisations are not meeting the regulatory factor requirements it could indicate non-compliance with data protection laws. Non-compliance with data protection laws can be measured using internal and external compliance audits and self-assessments. However, the objective of this research is to concentrate on the perception of consumers - whether they have confidence that 
organisations are meeting the regulatory factor requirements based on their experience when organisations process their personal information.

The compliance/meeting expectations block serves a second purpose, namely to establish if consumers' privacy expectations are met by organisations for each of the regulatory factor requirements by comparing the results of the privacy expectations to the results of the compliance/meeting expectations. Hence, the combined name for the block include the concept of compliance and meeting expectations.

- Gap. The privacy expectations versus compliance/meeting expectations are compared to establish whether there is a gap. Any discrepancy may indicate whether the expectations of consumers are higher, or in fact lower, than what they believe organisations are currently doing. This could give organisations insight into how to promote a trusting relationship through the social contract they enter into with consumers.

- Privacy concerns. The privacy concerns block was added to incorporate the concepts of existing information privacy perception instruments to establish the general privacy concerns of consumers, for instance, how concerned they are about sharing their personal identification numbers, compared to financial or health-related data. Together, the privacy expectations, compliance/meeting expectations and privacy concerns blocks are used as input to define the information privacy culture index (IPCI) of a given country.

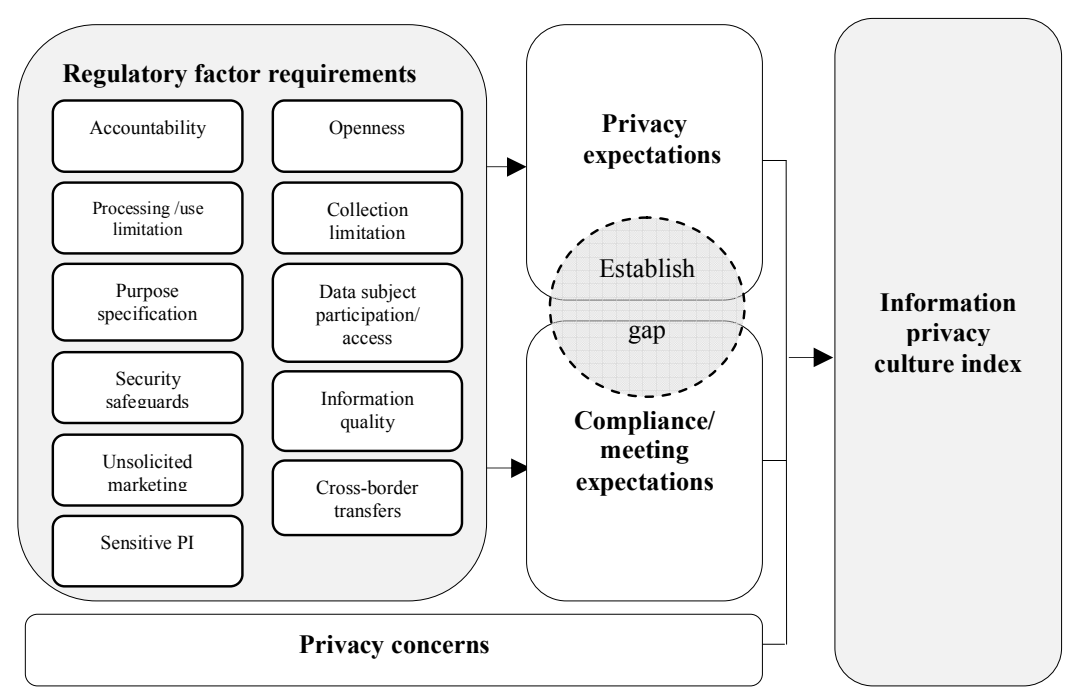

Figure 1: The information privacy culture index framework (IPCIF)

\section{The proposed information privacy culture index instrument}

The information privacy culture index instrument (IPCII) was developed based on the IPCIF. A number of questions were defined for each regulatory factor in figure 1, and were subsequently mapped to the relevant FIPP and OECD guideline. The questions were defined in pairs - one to measure the privacy expectation and a corresponding question to measure the compliance/meeting expectation about the same regulatory factor requirement. The questions in the privacy expectations section of the questionnaire were phrased starting with: "I expect ...". By contrast, questions in the compliance/meeting expectations section were phrased as: "I feel confident that organisations are ...". Using a five-point Likert scale for the privacy expectation section, the scale was defined as: I do not expect this; I sometimes expect this; Neutral; I mostly expect this; and I always expect this. For the compliance/meeting expectations questions, the following scale was used: Not at all confident; Somewhat confident; Neutral; Quite confident; and Very confident.

An expert panel, which reviewed the draft IPCII, consisted of an industry consultant who specialises in information privacy, a professor in Industrial Psychology who specialises in survey research methods as 
well as opinion and attitude surveys, and three academic lecturers teaching information privacy and POPIA at honours level. The panel was required to judge each question and indicate whether it is "essential" for measuring the regulatory factor requirement and whether the question is "clear" or "unclear". A number of adjustments were made to the draft IPCII to improve the user's understanding of the questions, and to align some questions more clearly with the objective of a specific factor. This improved the content validity of the IPCII questionnaire (Saunders, Lewis and Thornhill 2016). Table 1 gives an extract of two of the questions from the first privacy factor in the regulatory factor requirements block of figure 1, namely Processing/use limitation. The second column includes the mapping to POPIA, as the first data collection exercise was conducted in South Africa. The question pairs for each requirement are listed in columns three and four. Please refer to Appendix A for the complete questionnaire.

Table 1: Extracts of statements from the information privacy culture index instrument (IPCII)

\begin{tabular}{|l|l|l|l|}
\hline FIPP/OECD & POPIA mapping & Privacy expectations & Compliance/meeting expectations \\
\hline $\begin{array}{l}\text { Processing/ } \\
\text { use limitation }\end{array}$ & $\begin{array}{l}\text { Condition 2, section 9, } \\
\text { Processing limitation, } \\
\text { Lawfulness }\end{array}$ & $\begin{array}{l}\text { b. I expect organisations } \\
\text { to use my personal } \\
\text { information in a lawful } \\
\text { manner }\end{array}$ & $\begin{array}{l}\text { b. I feel confident that organisations } \\
\text { are using my personal information in } \\
\text { lawful ways }\end{array}$ \\
\hline $\begin{array}{l}\text { Processing/ } \\
\text { use limitation }\end{array}$ & $\begin{array}{l}\text { Condition 2, section 9, } \\
\text { Processing limitation, } \\
\text { Lawfulness }\end{array}$ & $\begin{array}{l}\text { c. I expect privacy when a } \\
\text { company has to processes } \\
\text { my personal information } \\
\text { for services or products }\end{array}$ & $\begin{array}{l}\text { c. I feel confident that organisations } \\
\text { respect my right to privacy when } \\
\text { collecting my personal information } \\
\text { for services or products }\end{array}$ \\
\hline
\end{tabular}

\section{Research method}

A survey method was employed using the IPCII to gather data from a representative sample of the South African population. This allowed the researcher to obtain numeric data about the attitudes or opinions of the population relating to the information privacy culture components (or constructs) (Creswell 2014). The data were analysed statistically to establish what the expectation and confident perceptions of consumers are. In addition, that data allowed the researcher to assess the internal consistency of the questionnaire applying the Cronbach alpha statistical test (Saunders et al. 2016).

While surveys are a cost-effective means of conducting research, they also have the benefit of including large samples of users or participants, which is necessary when seeking to obtain insight about the privacy culture across a nation (Brewerton and Millward 2002). However, care should be taken to ensure that the sample is representative, and that the measuring instrument produces reliable and valid data (Brewerton and Millward 2002). These aspects were considered as part of the research study.

\subsection{Sample}

The final questionnaire was converted to a web-based format. It was sent out to an opt-in database of the South African population, which is managed by a research organisation, Columinate (2018). Data were collected from 1 to 12 June 2017, and in total, 1007 responses were obtained. The data were deemed to be representative of the demographic profile of the South African population across gender, race, province and generation groups (see figure 2). The responses also ranged across industries and education levels to allow a representative sample across South Africa.

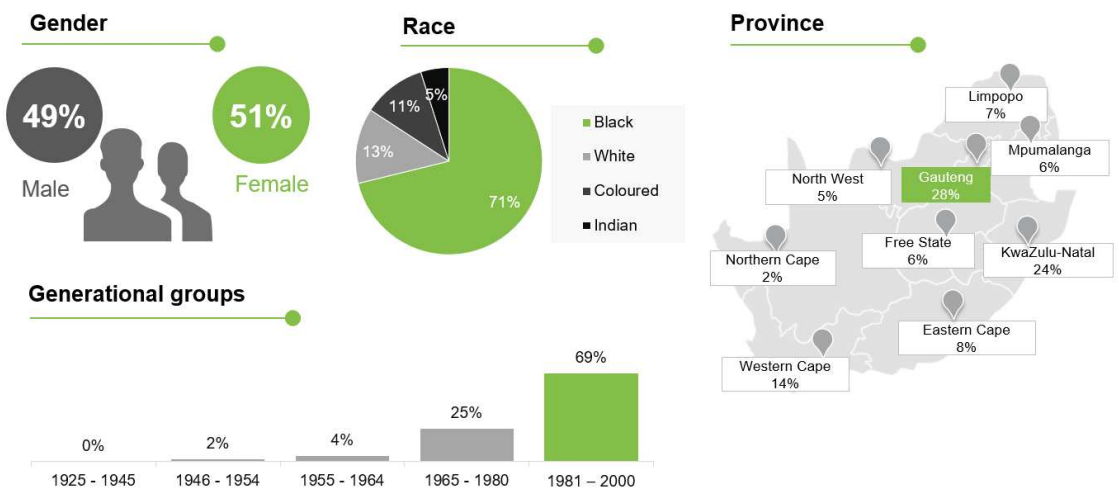




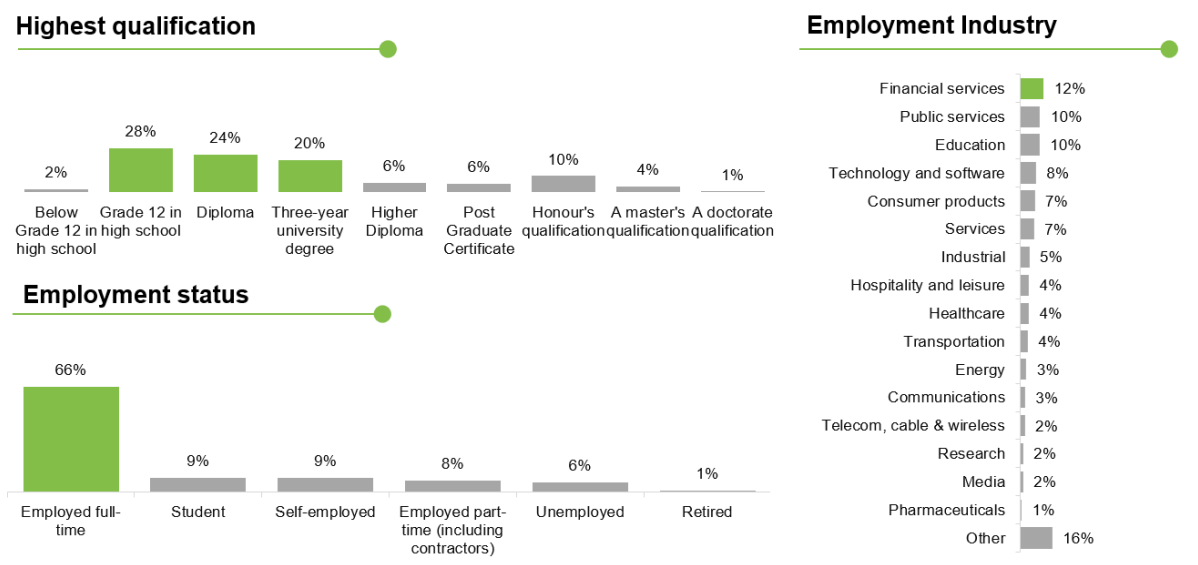

Figure 2: Responses obtained per province and race across South Africa

\section{Privacy concern perspective}

The data was analysed using the Statistical Package for the Social Sciences (SPSS), version 24. Over $80 \%$ of respondents expressed general concerns about the protection of their personal information. They were especially concerned about the safeguarding of their identity (94\%), and their financial (92\%) and health-related $(80 \%)$ data. In dealing with organisations, respondents expressed greater concern about sharing their personal information online (79\%), than in face-to-face transactions (57\%). Most respondents indicated that they currently obtain information about their privacy rights from the internet and from banking institutions, with more than half using their cellphones as the main platform for accessing the internet. While $62 \%$ claimed to know their privacy rights when dealing with organisations, $45 \%$ indicated that their knowledge on the topic was average. Only $37 \%$ indicated that they knew where to lodge complaints if their privacy rights had been violated by organisations.

\section{Results}

\subsection{Privacy expectations}

The overall mean for the privacy expectations section was 4.57 . Thus, $91.8 \%$ of respondents expressed the expectation that the regulatory factor requirements should be honoured when their personal information is processed. This indicates that there is a culture present with a high expectation towards privacy when organisations process consumers' personal information. Table 2 lists the means of each of the regulatory factor requirements. The regulatory factor requirements with the highest expectation, based on the mean, were related to security whereby consumers expect organisations to protect their personal information (4.75) by having the necessary technology and controls in place (4.70) and to safeguard this information when sending it to other countries (4.70). While South Africa's data protection act, POPIA (Republic of South Africa, 2013), has not commenced as yet, it is important for organisations to protect the personal information of their customers to build a relationship of trust by meeting the regulatory factor expectations of South African consumers.

\subsection{Compliance/meeting expectations}

The overall mean for the compliance/meeting expectations section was 3.02 , with a $42.3 \%$ confidence on the part of the respondents that organisations are indeed complying with regulatory factor requirements. For all regulatory factor requirement questions in the IPCII, the respondents indicated that they believe organisations are not meeting requirements. It appears that consumers are not confident that South African organisations are meeting the FIPPs and OECD guidelines, and that they are in breach of the regulatory requirements of POPIA, since POPIA maps to each of the regulatory factor requirements. Of concern is the fact that the respondents were not confident that organisations are using their personal information lawfully (3.02), or for the agreed purposes (2.87) and that consent is not always obtained (3.06). Further concerns were raised about the protection of personal information, direct marketing and 
cross-border transfers. This raises concerns as to whether the right to privacy, as outlined in section 14 of the Constitution of the Republic of South Africa, 1996, is maintained and what impact it has on the harmonisation with international data protection standards.

\subsection{Gap}

The means of the regulatory factor requirements measured in the privacy expectation and compliance/meeting expectations sections are depicted in table 2. A consolidated statement is provided for the privacy expectation and compliance/meeting expectations question pair (column one), with the respective means for each in columns two and three. The $t$ value is provided for the paired statements (column four). Column five, gap, outlines the gaps identified between the privacy expectations (column 2) for each of the regulatory factor requirements, and whether respondents were confident the organisation's behaviour was in line with the regulatory factor requirements (compliance/meeting expectations, column 3). A significant difference was identified for all question pairs based on the t-test results. The Sig. (2-tailed) value was 0.000 for all the question pairs (significant if $p<0.05$ ) and was supported by the high $\mathrm{t}$ values (Howell 1995). While respondents had high expectations for each regulatory factor requirement (see privacy expectation means), organisations seemed to fail to meet those requirements (see compliance/meeting expectations means).

Table 2: Privacy expectations versus compliance/meeting expectations and the related gap

\begin{tabular}{|c|c|c|c|c|}
\hline $\begin{array}{l}\text { Regulatory factor concepts (combined concept for } \\
\text { expectation and compliance section in IPCII) }\end{array}$ & $\begin{array}{c}\text { Privacy } \\
\text { expectation } \\
\text { mean }\end{array}$ & $\begin{array}{c}\text { Compliance/ } \\
\text { meeting } \\
\text { expectations } \\
\text { mean }\end{array}$ & $\mathbf{t}$ & Gap \\
\hline $\begin{array}{l}\text { a. Notify me before they start collecting my personal } \\
\text { information }\end{array}$ & 4.57 & 3.03 & 29.426 & 1.54 \\
\hline b. Use my personal information in a lawful manner & 4.68 & 3.02 & 31.480 & 1.66 \\
\hline $\begin{array}{l}\text { c. Privacy when a company has to process my personal } \\
\text { information for services or products }\end{array}$ & 4.64 & 3.04 & 30.894 & 1.6 \\
\hline $\begin{array}{l}\text { d. Not to collect excessive or unnecessary information from } \\
\text { me }\end{array}$ & 4.35 & 3.14 & 22.152 & 1.21 \\
\hline $\begin{array}{l}\text { e. Only collect my personal information when I have given } \\
\text { my consent, or for a legitimate business reason }\end{array}$ & 4.64 & 3.06 & 30.167 & 1.58 \\
\hline $\begin{array}{l}\text { f. Only collect my personal information from myself and not } \\
\text { from other sources }\end{array}$ & 4.55 & 3.01 & 29.785 & 1.54 \\
\hline $\begin{array}{l}\text { g. Explicitly define the purpose for which they want to use } \\
\text { my information }\end{array}$ & 4.65 & 3.05 & 31.521 & 1.6 \\
\hline $\begin{array}{l}\text { h. Only use my personal information for purposes I agreed } \\
\text { to and never for other purposes }\end{array}$ & 4.67 & 2.87 & 33.705 & 1.8 \\
\hline $\begin{array}{l}\text { i. Only keep my personal information for as long as required } \\
\text { for business purposes or regulatory requirements }\end{array}$ & 4.45 & 3.32 & 23.213 & 1.13 \\
\hline $\begin{array}{l}\text { j. Obtain my consent if they want to use my personal } \\
\text { information for purposes not agreed to with them }\end{array}$ & 4.62 & 2.96 & 31.020 & 1.66 \\
\hline k. Inform me of the conditions & 4.59 & 2.97 & 32.410 & 1.62 \\
\hline 1. Keep my personal information updated & 4.00 & 3.03 & 20.289 & 0.97 \\
\hline $\mathrm{m}$. Protect my personal information & 4.75 & 3.03 & 34.703 & 1.72 \\
\hline $\begin{array}{l}\text { n. Organisations to have all the necessary technology and } \\
\text { processes in place to protect my personal information }\end{array}$ & 4.70 & 3.13 & 31.642 & 1.57 \\
\hline $\begin{array}{l}\text { o. Ensure that third parties have all the necessary technology } \\
\text { and processes in place to protect my information }\end{array}$ & 4.64 & 2.99 & 32.985 & 1.68 \\
\hline $\begin{array}{l}\text { p. Inform me if records of my personal data were lost, } \\
\text { damaged or exposed publicly }\end{array}$ & 4.68 & 2.73 & 36.488 & 1.95 \\
\hline $\begin{array}{l}\text { q. Inform me what records or personal information they } \\
\text { have about me }\end{array}$ & 4.53 & 3.00 & 29.762 & 1.53 \\
\hline r. Correct or delete my personal information at my request & 4.57 & 3.01 & 29.787 & 1.56 \\
\hline s. Do not collect sensitive personal information about me & 4.28 & 3.00 & 23.580 & 1.28 \\
\hline $\begin{array}{l}\text { t. Honour my choice if I decide not to receive direct } \\
\text { marketing }\end{array}$ & 4.66 & 2.99 & 31.432 & 1.67 \\
\hline $\begin{array}{l}\text { u. Give me a choice whether I want to receive direct } \\
\text { marketing from them }\end{array}$ & 4.67 & 3.17 & 30.732 & 1.5 \\
\hline $\begin{array}{l}\text { v. Protect my information when they have to send it to other } \\
\text { countries }\end{array}$ & 4.70 & 2.92 & 35.243 & 1.78 \\
\hline
\end{tabular}

\section{Validating the information privacy culture index instrument (IPCII)}

The IPCII was subjected to an exploratory factor analysis (EFA) using the principle component analysis with the varimax rotation. The EFA was conducted on the items in the expectation and confidence 
constructs. The data collected were subject to Bartlett's test of sphericity and the Kaiser-Meyer-Olkin (KMO) measure of sampling adequacy, to test the aptness of the sample for the EFA (O'Rourke and Hatcher 2013). Bartlett's test of sphericity should be significant $(p<0.05)$, to indicate sampling adequacy (Howell 1995). In this research study, Bartlett's test was significant at $\mathrm{p}<0.00$ for the expectations and compliance / meeting expectations (confidence) constructs adding further evidence to sampling validity.

The KMO should be 0.60 or higher in order to proceed with factor analysis (O'Rourke and Hatcher 2013). In the expectations construct, three components (factors), see table 3, were identified with a KMO value of 0.950 and an eigenvalue larger than one. Kaiser (1960) recommends retaining all factors with eigenvalues greater than 1 . All item loadings in the expectations construct were above 0.4 , which is considered the minimum criterion to retain items in a factor (Field 2009).

Table 3: Privacy expectations table

\begin{tabular}{|c|c|c|c|c|}
\hline \multirow{2}{*}{ Privacy expectation construct statements } & \multirow{2}{*}{$\begin{array}{l}\text { IPCI requirements and } \\
\text { mapping to POPIA }\end{array}$} & \multicolumn{3}{|c|}{ Component } \\
\hline & & 1 & 2 & 3 \\
\hline $\begin{array}{l}\text { Q24k. I expect companies to inform me of the conditions for } \\
\text { processing my personal information }\end{array}$ & $\begin{array}{c}\text { Openness (Condition 6, } \\
\text { section 18) }\end{array}$ & 0.557 & & \\
\hline $\begin{array}{l}\text { Q24m. I expect companies to protect my personal } \\
\text { information }\end{array}$ & $\begin{array}{c}\text { Security } \\
\text { (Condition } 7 \text {, section } 19)\end{array}$ & 0.673 & & \\
\hline $\begin{array}{l}\text { Q24n. I expect companies to have all the necessary } \\
\text { technology and processes in place to protect my personal } \\
\text { information }\end{array}$ & $\begin{array}{c}\text { Security } \\
\text { (Condition 7, section 19) }\end{array}$ & 0.687 & & \\
\hline $\begin{array}{l}\text { Q24o. I expect companies to ensure that their third parties } \\
\text { (processing my personal information) have all the necessary } \\
\text { technology and processes in place to protect my personal } \\
\text { information }\end{array}$ & $\begin{array}{c}\text { Security } \\
\text { (Condition } 7 \text {, section } 20 \& \\
21 \text { ) }\end{array}$ & 0.623 & & \\
\hline $\begin{array}{l}\text { Q24p. I expect companies to inform me if records of my } \\
\text { personal data were lost, damaged or exposed publicly }\end{array}$ & $\begin{array}{c}\text { Security } \\
\text { (Condition } 7, \text { section 22) }\end{array}$ & 0.587 & & \\
\hline $\begin{array}{l}\text { Q24q. I expect companies to tell me what records of } \\
\text { personal information they have about me when I enquire } \\
\text { about it }\end{array}$ & $\begin{array}{l}\text { Data subject participation } \\
\text { (Condition } 8, \text { section } 23 \text { ) }\end{array}$ & 0.550 & & \\
\hline $\begin{array}{l}\text { Q24r. I expect companies to correct or delete my personal } \\
\text { information at my request }\end{array}$ & $\begin{array}{l}\text { Data subject participation } \\
\text { (Condition } 8, \text { section } 24)\end{array}$ & 0.638 & & \\
\hline $\begin{array}{l}\text { Q24t. I expect companies to honour my choice if I decide } \\
\text { not to receive direct marketing }\end{array}$ & $\begin{array}{l}\text { Unsolicited marketing } \\
\text { (Section 69) }\end{array}$ & 0.704 & & \\
\hline $\begin{array}{l}\text { Q24u. I expect companies to give me a choice if I want to } \\
\text { receive direct marketing from them }\end{array}$ & $\begin{array}{l}\text { Unsolicited marketing } \\
\text { (Section 69) }\end{array}$ & 0.679 & & \\
\hline $\begin{array}{l}\text { Q24v. I expect companies to protect my information when } \\
\text { they have to send it to other countries }\end{array}$ & $\begin{array}{l}\text { Cross-border transfers } \\
\text { (Section 72) }\end{array}$ & 0.694 & & \\
\hline $\begin{array}{l}\text { Q24a. I expect companies to notify me before they start } \\
\text { collecting my personal information }\end{array}$ & $\begin{array}{c}\text { Openness } \\
\text { (Condition } 6, \text { section } 18)\end{array}$ & & 0.533 & \\
\hline $\begin{array}{l}\text { Q24b. I expect companies to use my personal information in } \\
\text { a lawful manner }\end{array}$ & $\begin{array}{l}\text { Processing / Use Limitation } \\
\text { (Condition 2, section 9) }\end{array}$ & & 0.766 & \\
\hline $\begin{array}{l}\text { Q24c. I expect privacy when a company has to processes } \\
\text { my personal information for services or products }\end{array}$ & $\begin{array}{l}\text { Processing / Use Limitation } \\
\text { (Condition 2, section 9) }\end{array}$ & & 0.737 & \\
\hline $\begin{array}{l}\text { Q24e. I expect companies to only collect my personal } \\
\text { information when I have given my consent; or if it is } \\
\text { necessary for a legitimate business reason }\end{array}$ & $\begin{array}{l}\text { Processing / Use Limitation } \\
\text { (Condition 2, section 11) }\end{array}$ & & 0.689 & \\
\hline $\begin{array}{l}\text { Q24f. I expect companies to only collect my personal } \\
\text { information from myself and not from other sources }\end{array}$ & $\begin{array}{l}\text { Processing / Use Limitation } \\
\text { (Condition 2, section 12) }\end{array}$ & & 0.634 & \\
\hline $\begin{array}{l}\text { Q24g. I expect companies to explicitly define the purpose } \\
\text { for which they want to use my information }\end{array}$ & $\begin{array}{l}\text { Purpose specification } \\
\text { (Condition } 3 \text {, section } 13 \text { ) }\end{array}$ & & 0.636 & \\
\hline $\begin{array}{l}\text { Q24h. I expect companies to only use my personal } \\
\text { information for purposes I agreed to and never for other } \\
\text { purposes }\end{array}$ & $\begin{array}{l}\text { Purpose specification } \\
\text { (Condition 3, section 13) }\end{array}$ & & 0.678 & \\
\hline $\begin{array}{l}\text { Q24j. I expect companies to obtain my consent if they want } \\
\text { to use my personal information for purposes not agreed to } \\
\text { with them }\end{array}$ & $\begin{array}{c}\text { Further processing } \\
\text { (Condition } 4 \text {, section } 15 \text { ) }\end{array}$ & & 0.434 & \\
\hline $\begin{array}{l}\text { Q24d. I expect companies not to collect excessive or } \\
\text { unnecessary information from me than what is needed for } \\
\text { them to offer me a service or product }\end{array}$ & $\begin{array}{l}\text { Processing / Use Limitation } \\
\text { (Condition 2, section 10) }\end{array}$ & & & 0.473 \\
\hline $\begin{array}{l}\text { Q24i. I expect companies to only keep my personal } \\
\text { information for as long as required for business purposes or } \\
\text { regulatory requirements }\end{array}$ & $\begin{array}{l}\text { Purpose specification } \\
\text { (Condition } 3 \text {, section } 14)\end{array}$ & & & 0.575 \\
\hline $\begin{array}{l}\text { Q24l. I expect companies to keep my personal information } \\
\text { updated }\end{array}$ & $\begin{array}{l}\text { Quality (Condition 6, } \\
\text { section 16) }\end{array}$ & & & 0.724 \\
\hline $\begin{array}{l}\text { Q24s. I expect companies not to collect sensitive personal } \\
\text { information about me (e.g. information on my children, } \\
\text { religious beliefs, race or ethnic origin, trade union } \\
\text { membership, political persuasion, health or sex life, criminal } \\
\text { record or biometric information) }\end{array}$ & $\begin{array}{l}\text { Sensitive PI } \\
\text { (section 26) }\end{array}$ & & & 0.653 \\
\hline
\end{tabular}


In the compliance/meeting expectations construct, one component (factor) was identified with a KMO value of 0.984 . All item loadings in the compliance/meeting expectations construct were above 0.4 (see table 4).

Table 4: Compliance/meeting expectations table

\begin{tabular}{|c|c|c|}
\hline \multirow[t]{2}{*}{ Compliance/meeting expectations statement constructs } & \multirow[t]{2}{*}{$\begin{array}{l}\text { IPCI requirements and } \\
\text { mapping POPIA }\end{array}$} & Component \\
\hline & & 1 \\
\hline $\begin{array}{l}\text { Q25a. I feel confident that companies are notifying me before } \\
\text { collecting my personal information }\end{array}$ & $\begin{array}{c}\text { Openness (Condition } 6 \text {, section } \\
18 \text { ) }\end{array}$ & 0.804 \\
\hline $\begin{array}{l}\text { Q25b. I feel confident that companies are using my personal } \\
\text { information in lawful ways (e.g. never sell my information, publish } \\
\text { my confidential information, or use my information for fraudulent } \\
\text { transactions) }\end{array}$ & $\begin{array}{l}\text { Processing / Use Limitation } \\
\quad \text { (Condition 2, section 9) }\end{array}$ & 0.854 \\
\hline $\begin{array}{l}\text { Q25c. I feel confident that companies respect my right to privacy } \\
\text { when collecting my personal information for services or products } \\
\text { (e.g. never to share my information with unauthorised personnel or } \\
\text { use my information for other purposes) }\end{array}$ & $\begin{array}{l}\text { Processing / Use Limitation } \\
\text { (Condition 2, section 9) }\end{array}$ & 0.871 \\
\hline $\begin{array}{l}\text { Q25d. I feel confident that companies are requesting only relevant } \\
\text { and not information other than what is needed for them to offer me } \\
\text { a service or product. (e.g. information on my children, my salary, } \\
\text { my health, my race or religion) }\end{array}$ & $\begin{array}{l}\text { Processing / Use Limitation } \\
\text { (Condition 2, section 10) }\end{array}$ & 0.814 \\
\hline $\begin{array}{l}\text { Q25e. I feel confident that companies are collecting my personal } \\
\text { information only with my consent, or for a legitimate business } \\
\text { reason (e.g. not collecting my information without my consent } \\
\text { while I browse the internet, or buying my information from other } \\
\text { companies) }\end{array}$ & $\begin{array}{l}\text { Processing / Use Limitation } \\
\text { (Condition 2, section 11) }\end{array}$ & 0.846 \\
\hline $\begin{array}{l}\text { Q25f. I feel confident that companies are collecting my personal } \\
\text { information from legitimate sources }\end{array}$ & $\begin{array}{l}\text { Processing / Use Limitation } \\
\text { (Condition 2, section 12) }\end{array}$ & 0.790 \\
\hline $\begin{array}{l}\text { Q25g. I feel confident that companies are explicitly defining the } \\
\text { purpose they want to use my information for }\end{array}$ & $\begin{array}{l}\text { Purpose specification } \\
\text { (Condition } 3 \text {, section } 13 \text { ) }\end{array}$ & 0.849 \\
\hline $\begin{array}{l}\text { Q25h. I believe that companies are only using my personal } \\
\text { information for purposes I agreed to and never for other purposes } \\
\text { (e.g. telemarketing, targeted advertising) }\end{array}$ & $\begin{array}{l}\text { Purpose specification } \\
\text { (Condition } 3 \text {, section 13) }\end{array}$ & 0.859 \\
\hline $\begin{array}{l}\text { Q25i. I believe that companies are keeping my personal information } \\
\text { indefinitely }\end{array}$ & $\begin{array}{l}\text { Purpose specification } \\
\text { (Condition } 3 \text {, section } 14 \text { ) }\end{array}$ & 0.572 \\
\hline $\begin{array}{l}\text { Q25j. I feel confident that companies are obtaining my consent to } \\
\text { use my personal information for purposes other than those agreed to } \\
\text { with me }\end{array}$ & $\begin{array}{c}\text { Further processing } \\
\text { (Condition } 4, \text { section } 15)\end{array}$ & 0.771 \\
\hline $\begin{array}{l}\text { Q25k. I feel confident that companies adequately inform me of the } \\
\text { conditions (e.g. purposes, consequences, recipients of my } \\
\text { information, my rights and the way in which they protect } \\
\text { confidentiality) for processing my personal information }\end{array}$ & $\begin{array}{c}\text { Openness } \\
\text { (Condition 6, section 18) }\end{array}$ & 0.855 \\
\hline $\begin{array}{l}\text { Q251. I feel confident that companies keep my personal information } \\
\text { up to date }\end{array}$ & $\begin{array}{c}\text { Quality } \\
\text { (Condition 6, section 16) }\end{array}$ & 0.793 \\
\hline $\begin{array}{l}\text { Q25m. I feel confident that companies are protecting my personal } \\
\text { information (e.g. keep my data confidential and protect it from } \\
\text { being accessed by unauthorised parties) }\end{array}$ & $\begin{array}{c}\text { Security } \\
\text { (Condition 7, section 19) }\end{array}$ & 0.887 \\
\hline $\begin{array}{l}\text { Q25n. I feel confident that companies have all the necessary } \\
\text { technology and processes in place to protect my personal } \\
\text { information }\end{array}$ & $\begin{array}{c}\text { Security } \\
\text { (Condition 7, section 19) }\end{array}$ & 0.857 \\
\hline $\begin{array}{l}\text { Q25o. I feel confident that companies ensure that their third parties } \\
\text { have all the necessary technology and processes in place to protect } \\
\text { my personal information }\end{array}$ & $\begin{array}{c}\text { Security } \\
\text { (Condition 7, section } 20 \& 21)\end{array}$ & 0.851 \\
\hline $\begin{array}{l}\text { Q25p. I feel confident that companies inform me if records of my } \\
\text { personal data were lost, damaged or exposed publicly }\end{array}$ & $\begin{array}{c}\text { Security } \\
\text { (Condition 7, section 22) } \\
\end{array}$ & 0.845 \\
\hline $\begin{array}{l}\text { Q25q. I feel confident that companies can tell me what records or } \\
\text { personal information they have about me }\end{array}$ & $\begin{array}{l}\text { Data subject participation } \\
\text { (Condition 8, section 23) }\end{array}$ & 0.833 \\
\hline $\begin{array}{l}\text { Q25r. I feel confident that companies will correct or delete my } \\
\text { personal information at my request }\end{array}$ & $\begin{array}{l}\text { Data subject participation } \\
\text { (Condition } 8 \text {, section } 24 \text { ) }\end{array}$ & 0.840 \\
\hline $\begin{array}{l}\text { Q25s. I feel confident that companies only collect sensitive } \\
\text { personal information (e.g. information on my children, religious } \\
\text { beliefs, race or ethnic origin, trade union membership, political } \\
\text { persuasion, health or sex life, criminal record or biometric } \\
\text { information) about me with my explicit consent. }\end{array}$ & $\begin{array}{l}\text { Sensitive PI } \\
\text { (section 26) }\end{array}$ & 0.716 \\
\hline $\begin{array}{l}\text { Q25t. I feel confident that companies honour my choice if I do not } \\
\text { want to receive direct marketing }\end{array}$ & $\begin{array}{l}\text { Unsolicited marketing } \\
\text { (Section 69) }\end{array}$ & 0.813 \\
\hline $\begin{array}{l}\text { Q25u. Companies always give me a choice to indicate if I want to } \\
\text { receive direct marketing from them }\end{array}$ & $\begin{array}{l}\text { Unsolicited marketing } \\
\text { (Section 69) }\end{array}$ & 0.729 \\
\hline $\begin{array}{l}\text { Q25v. I feel confident that companies protect my information if } \\
\text { they have to send it to other countries }\end{array}$ & $\begin{array}{l}\text { Cross-border transfers } \\
\text { (Section 72) }\end{array}$ & 0.825 \\
\hline $\begin{array}{l}\text { Q25w. I feel confident that if I submit a complaint it will be dealt } \\
\text { with appropriately by the relevant authorities }\end{array}$ & $\begin{array}{l}\text { Procedure for dealing with } \\
\text { complaints (Section 63) } \\
\text { (No corresponding question in } \\
\text { the expectations construct) }\end{array}$ & 0.808 \\
\hline $\begin{array}{l}\text { Q25x. I believe that organisations take their responsibility seriously } \\
\text { to protect my personal information }\end{array}$ & $\begin{array}{l}\text { Accountability (Condition 1) } \\
\text { (No corresponding question in } \\
\text { the expectations construct) }\end{array}$ & 0.860 \\
\hline
\end{tabular}


The new factors were named, as displayed in table 5, with the aim of summarising the key concepts included in each factor. The Cronbach alpha for the identified factors were all above 0.8 , indicating a good reliability, except for factor C. Saunders et al. (2016) recommend a minimum cut-off of 0.70. However, Cronbach alpha loadings of $0.60-0.70$ can be accepted (HR Statistics 2017). If more statements are added to factor $\mathrm{C}$, it should increase the Cronbach alpha coefficient. As such, additional items will be added to factor $\mathrm{C}$ in future research with the aim of improving the Cronbach alpha value.

Table 5: New factors and Cronbach alpha values

\begin{tabular}{|l|c|c|}
\hline Factors & $\begin{array}{c}\text { Number of } \\
\text { items }\end{array}$ & Cronbach alpha \\
\hline Factor A: Information protection expectations & 10 & 0.895 \\
\hline Factor B: Information usage expectations & 8 & 0.873 \\
\hline Factor C: Information collection expectation & 4 & 0.642 \\
\hline $\begin{array}{l}\text { Factor D: Confidence in meeting privacy } \\
\text { expectations and compliance requirements }\end{array}$ & 24 & 0.978 \\
\hline
\end{tabular}

\section{Discussion}

The IPCII indicates that South Africans have high expectations regarding privacy. They are concerned about sharing their personal, financial and health-related data - especially in an online context. While indications are that privacy rights are not always protected in an online context in South Africa (Da Veiga and Swartz 2017), the index reveals that consumers are not confident that organisations in general are processing their information in line with FIPPs, or with POPIA regulatory requirements. In addition, they are unsure which recourse to take if their rights are violated. There seems to be a disconnect between what consumers expect in terms of privacy, and how consumers believe organisations are honouring those expectations, resulting in a breach of trust and the social contract being violated. As South Africans do not have a clear understanding of what their privacy rights entail, there is a need for awareness-raising and education initiatives on the part of government, the Information Regulator, as well as organisations. Organisations should engage in internal gap and compliance assessments to establish which of the regulatory factors they are contravening. That would enable them to implement measures and controls that comply with POPIA requirements.

The validated IPCI consist of four factors that can be used across countries to establish what the privacy expectations and confidence levels of consumers are. The full questionnaire is included in Appendix A. Further research will incorporate data collection in other countries, with a view to building a national information privacy culture index for comparison purposes, using a dashboard.

\section{Conclusion}

An information privacy culture index framework and validated information privacy culture index instrument are proposed in this paper. The objective is to measure privacy perceptions across nations by focusing on consumers' privacy expectations, their actual experiences when organisations process their personal information and general privacy concerns against the backdrop of FIPPs and OECD privacy guidelines. Data from the information privacy culture index instrument, which has been rolled out in South Africa, proved valuable in identifying gaps between consumers' information privacy expectations and what they believe is happening in reality - a scenario which has resulted in a breach of trust and the social contract being violated. In addition, it indicated that consumers have a low level of confidence that organisations are behaving in line with the FIPPs and OECD privacy guidelines as mapped to POPIA. The government, Information Regulator and organisations can leverage the results of the proposed index in order to implement controls aimed at addressing any gaps identified from a consumer and compliance perspective. The index can also be monitored over time to identify where changes are needed. Future research will focus on the inclusion of other countries, and comparisons between demographic groups.

\section{Acknowledgement}

This work is based on research supported wholly by the National Research Foundation of South Africa (grant number: 105735). 


\section{References}

Australian Government (1988), Privacy Act, Act 119 of 1988, available at: https://www.legislation.gov.au/Series/C2004A03712 (accessed 16 February 2018).

Australian Government (2018), "Office of the Australian Information Commissioner, Statements", available at: https://www.oaic.gov.au/media-and-speeches/statements/ (accessed 16 February 2018).

Bellman, S., Johnson, E.J., Kobrin, S.K. and Lohse, G.L. (2004), "International differences in information privacy concerns: a global survey of consumers", The Information Society, Vol. 20, pp. 313-324.

Business Dictionary (2018), "National-culture", available at: http://www.businessdictionary.com/definition/nationalculture.html (accessed 16 February 2018).

Brewerton, P. and Millward, L. (2002), Organizational research methods, Sage, London.

Columinate (2018), available at: https://www.columinate.com (accessed 16 February 2018).

Creswell, J.W. (2014), Research design, qualitative, quantitative, and mixed method approaches, Sage, Los Angeles, CA.

Da Veiga, A. and Martins N. (2015), "Information security culture and information protection culture: a validated assessment instrument", Computer Law and Security Review, Vol. 31 No. 2015, pp. 243-256.

Da Veiga, A. (2017), "An Information Privacy Culture Index Framework and Instrument to Measure Privacy Perceptions across Nations: Results of an Empirical Study”, In Furnell, S. and Clarke N. (eds.), Proceedings of the Eleventh International Symposium on Human Aspects of Information Security \& Assurance (HAISA 2017), Australia, Adelaide, pp. 196-205, ISBN: 978-1-84102-428-8.

Da Veiga, A. and Swartz, P. (2017), "Personal information and regulatory requirements for direct marketing: a South African insurance industry experiment", Research Journal of the South African Institute of Electrical Engineering (SAIEE), Vol. 108 No. 2, pp. 56-70.

Dell EMC (2015), "The EMC Privacy Index, global \& in-depth country results", available at: https://www.emc.com/collateral/brochure/privacy-index-global-in-depth-results.pdf (accessed 16 February 2018).

Deloitte \& Touche (2017), “Australian Privacy Index”, available at: https://www2.deloitte.com/au/en/pages/risk/articles/deloitte-australian-privacy-index-2017.html (accessed 16 February 2018).

DLA Piper (2018), "Data protection laws of the world", available at: https://www.dlapiperdataprotection.com/index.html (accessed 16 February 2018).

European Commission (2015), "Special Eurobarometer 431, data protection report", available at: http://ec.europa.eu/commfrontoffice/publicopinion/archives/ebs/ebs_431_en.pdf (accessed 19 October 2017).

European Commission (2016), "Flash Eurobarometer 443, e-Privacy Report", available at: https://ec.europa.eu/digitalsingle-market/en/news/eurobarometer-eprivacy (accessed 16 February 2018).

European Parliament and Council (2016), General Data Protection Regulation (GDPR), Regulation (EU) 2016/679, Official Journal of the European Parliament, available at: http://ec.europa.eu/justice/dataprotection/reform/files/regulation_oj_en.pdf (accessed 16 February 2018).

Fair Information Practice Principles (FIPP) (2018), IT Law Wikia, available at: http://itlaw. wikia.com/wiki/Fair_Information_Practice_Principles (accessed 16 February 2018).

Field, A. (2009), Discovering statistics using SPSS, 3rd edition, Sage Publications, London.

Great Britain (1998), Data Protection Act, London, Stationery Office, available at: http://www.legislation.gov.uk/ukpga/1998/29/contents (accessed 16 February 2018).

Greenleaf, G. (2014), "Sheherezade and the 101 data privacy laws: origins, significance and global trajectories", Journal of Law, Information \& Science, Vol. 23 No. 1, pp. 1-48.

Hofstede, G., Hofstede, G.J. and Minkov, M. (2010), Cultures and organizations: software of the mind, 3rd ed, McGraw-Hill, New York, NY.

Howell, D.C. (1995), Fundamental statistics for the behavioural sciences, third edition, International Thomson Publishing, California.

HR Statistics (2017), Quantitative research design, HR Statistics Pty, South Africa.

Information Commission Office (ICO) of the United Kingdom (2017), "Actions we've taken", available at: https://ico.org.uk/action-weve-taken/ (accessed 16 February 2018).

Information Systems Audit and Control Association (ISACA) (2016), ISACA privacy principles and program management guide, ISACA, Rolling Meadows, IL.

Kaiser, H.F. (1960), "The application of electronic computers to factor analysis", Educational and Psychological Measurement, Vol. 20 No. 1, pp. 141-151.

Kemp, R., and Moore, A. D. (2007). "Privacy”, Library Hi Tech, Vol. 25 No. 1, pp. 58-78.

KPMG (2016), "Survey reveals consumers' data privacy concerns", available at: https://home.kpmg.com/sg/en/home/media/press-releases/2016/11/companies-that-fail-to-see-privacy-as-a-businesspriority-risk-crossing-the-creepy-line.html (accessed 16 February 2018).

Kumaraguru, P. and Cranor, L.F. (2005), "Privacy indexes: a survey of Westin's studies", Carnegie Mellon Univ. CMU-ISRI-5-138.

Malhotra, N.K., Kim, S.S. and Agarwal, J. (2004), "Internet users' information privacy concerns (IUIPC): The construct, the scale, and a causal model", Information Systems Research, Vol. 15 No. 4, pp. 336-355.

Miltgen, C. (2009), "Online consumer privacy concerns and willingness to provide personal data on the internet", International Journal of Networking and Virtual Organisations, Vol. 6 No. 6, pp. 574-603.

Moore, A. (2008), "Defining privacy”, Journal of Social Philosophy, Vol. 39 No. 3, pp. 411-428. 
Morton, A. and Sasse, A.M. (2014), "Desperately seeking assurances: segmenting users by their information-seeking preferences." In the Twelfth Annual International Conference on Privacy, Security and Trust, Toronto, Canada: IEEE, pp. 102-111.

NCSA (2016), TRUSTe/NCSA Consumer Privacy Infographic - US Edition, available at: https://www.trustarc.com/resources/privacy-research/ncsa-consumer-privacy-index-us/ (accessed 16 February 2018).

O'Rourke, N. and Hatcher, A. (2013). A step-by-step approach to using SAS for factor analysis and structural equation modelling, SAS Institute, Cary, NC.

Phelps, J., Nowak, G. and Ferrell, E. (2000), "Privacy concerns and consumer willingness to provide personal information", Journal of Public Policy and Marketing, Vol. 19 No. 1, pp. 27-41.

Republic of South Africa (2013), The Protection of Personal Information Act, Act 4 of 2013. Pretoria, Government Printer, available at: http://www.justice.gov.za/legislation/acts/2013-004.pdf (accessed 5 September 2017).

Saunders, M., Lewis, P. and Thornhill, A. (2016), Research methods for business students, 7th ed., Pearson Education, Harlow.

Smith, H.J., Milberg, S.J. and Burke, S.J. (1995), "Information privacy: measuring individual's concerns about organisational practice", MIS Quarterly, June, pp. 167-195.

Swire, P.P. and Ahmad, K. (2012), Foundations of information privacy and data protection, a survey of global concepts, laws and practices, International Association of Privacy Professionals, Portsmouth, NH.

Symantec (2015), "State of privacy report", available at: https://www.symantec.com/content/en/us/about/presskits/bstate-of-privacy-report-2015.pdf (accessed 16 February 2018).

Woodruff, A., Pihus, V. and Consolvo, S. (2014), "Would a privacy fundamentalist sell their DNA for $\$ 1000 \ldots$ if nothing bad happened as a result? The Westin Categories, Behavioral Intentions, and Consequences", In: Tenth Symposium on Usable Privacy and Security (SOUPS), USENIX Association, Menlo Park, CA, pp. 1-18. 


\section{The following questions are aimed at getting to know you better:}

1. In which province do you reside?

\begin{tabular}{|l|l|}
\hline Gauteng & \\
\hline KwaZulu-Natal & \\
\hline Limpopo & \\
\hline North West & \\
\hline Mpumalanga & \\
\hline Free State & \\
\hline Western Cape & \\
\hline Eastern Cape & \\
\hline Northern Cape & \\
\hline
\end{tabular}

2. Please indicate your race:

\begin{tabular}{|l|l|}
\hline Black & \\
\hline Coloured & \\
\hline Indian & \\
\hline Asian & \\
\hline White & \\
\hline
\end{tabular}

3. When were you born?

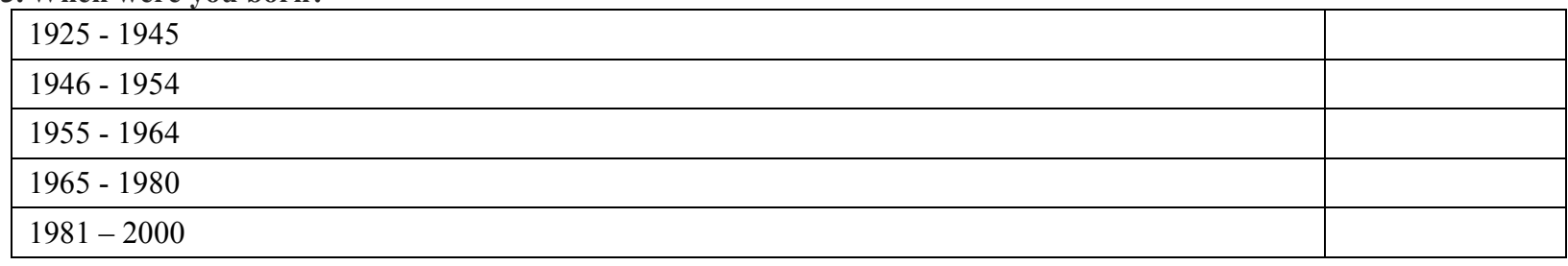

4. Are you...

\begin{tabular}{|l|l|}
\hline Male & \\
\hline Female & \\
\hline
\end{tabular}

5. What is your highest qualification?

Below Grade 12 in high school

Grade 12 in high school

Diploma

Three-year university degree

Higher Diploma

Post Graduate Certificate

Honour's qualification

Master's qualification

Doctorate qualification

None 
6. What is your employment status?

\begin{tabular}{|l|l|}
\hline Employed full-time & \\
\hline Employed part-time (including contractors) & \\
\hline Self-employed & \\
\hline Unemployed & \\
\hline Retired & \\
\hline Student & \\
\hline
\end{tabular}

7. Please indicate which of the following best describes the industry you work in:



8. What is your total monthly personal income before tax?

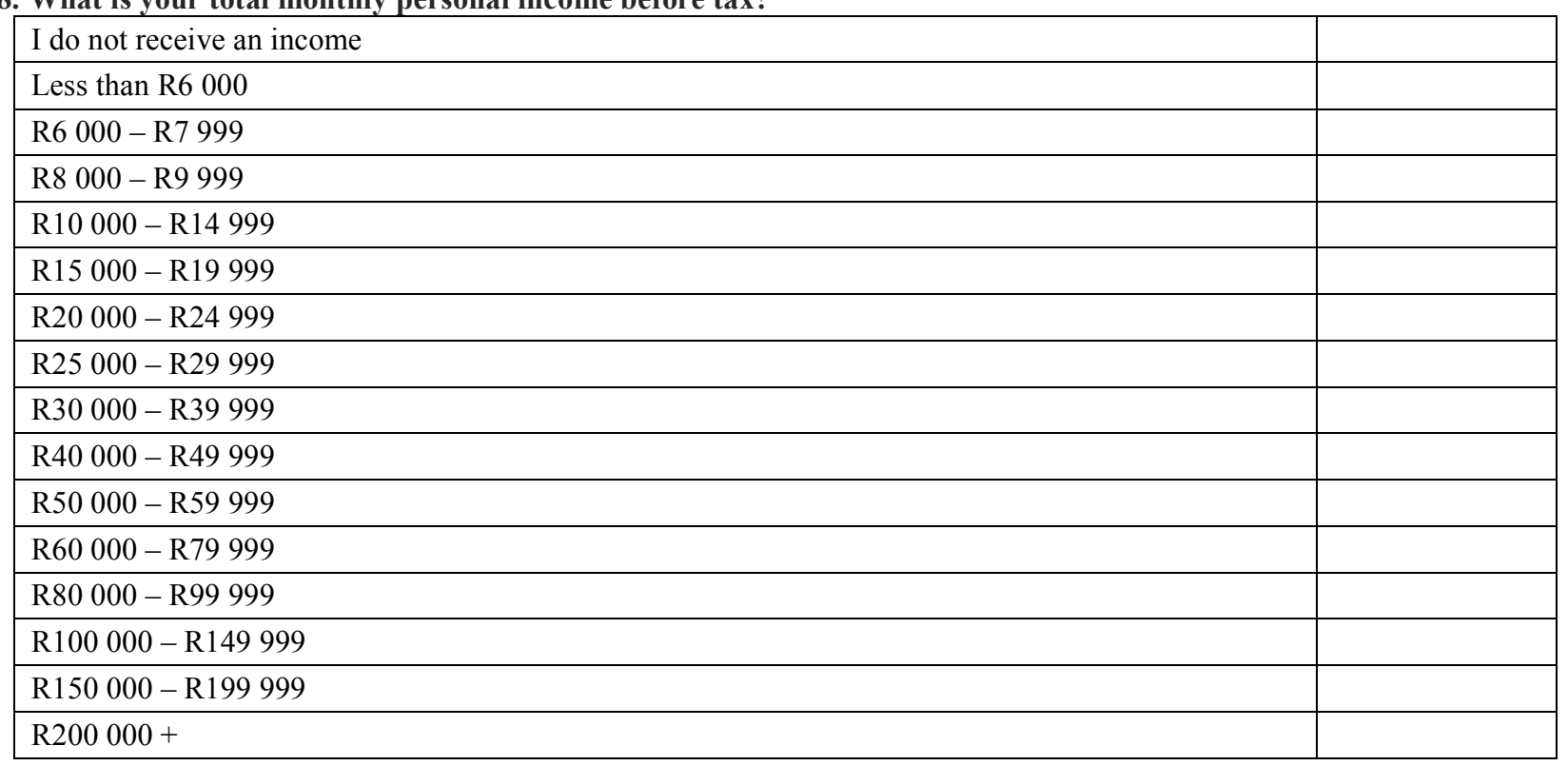


In the following section, we would like to know more about your internet use and knowledge of your privacy rights.

9. What device do you mostly use to access the internet?

\begin{tabular}{|l|l|}
\hline Cellphone & \\
\hline Laptop & \\
\hline Tablet & \\
\hline Desktop & \\
\hline
\end{tabular}

10. Please indicate for what purposes you use your devices when connected to the internet:

\begin{tabular}{|l|l|}
\hline Browsing the internet & \\
\hline Internet banking & \\
\hline Social media, such as Facebook, Twitter and so forth & \\
\hline Playing games & \\
\hline Maps and navigation & \\
\hline Instant messages, for example, SMS or WhatsApp, chat programmes & \\
\hline Downloading videos, music or books & \\
\hline Sending and receiving e-mails & \\
\hline Using online applications (GPS, health, financial etc.) & \\
\hline Saving information in the cloud: photos in Dropbox & \\
\hline Making phone calls & \\
\hline Selling products/services & \\
\hline Buying products/services & \\
\hline Other (To specify in open ended) & \\
\hline
\end{tabular}

10b. Please specify for what purposes you use your devices when connected to the internet.

11. How concerned are you about the protection of your personal information?

\begin{tabular}{|l|l|}
\hline Not concerned & \\
\hline Somewhat concerned & \\
\hline Neutral & \\
\hline Extremely concerned & \\
\hline
\end{tabular}

12. How would you rate your knowledge of your privacy rights?

\begin{tabular}{|l|l|}
\hline Very poor & \\
\hline Poor & \\
\hline Average & \\
\hline Good & \\
\hline Very good & \\
\hline
\end{tabular}


13. How concerned are you to share your personal information with companies on the internet?

\begin{tabular}{|l|l|}
\hline Not concerned & \\
\hline Somewhat concerned & \\
\hline Neutral & \\
\hline Concerned & \\
\hline Extremely concerned & \\
\hline
\end{tabular}

14. How concerned are you to share your personal information with companies in everyday business transactions that do not involve the internet? (ie face to face transactions)

\begin{tabular}{|l|l|}
\hline Not concerned & \\
\hline Somewhat concerned & \\
\hline Neutral & \\
\hline Concerned & \\
\hline Extremely concerned & \\
\hline
\end{tabular}

15. Do you know what your privacy rights are to protect your personal information when providing it to a company (what rights you have to privacy and confidentiality of your personal information when providing your information to a company)?

\begin{tabular}{|l|l|}
\hline Yes & \\
\hline No & \\
\hline
\end{tabular}

16. Have you or your immediate family members experienced personal loss, financial loss or harm as a result of my personal information that was misused/lost/shared by a company?

\begin{tabular}{|l|l|}
\hline Yes & \\
\hline No & \\
\hline
\end{tabular}

17. Do you know of someone whose personal information has been misused by another person (conducted fraudulent transactions, exposed confidential information)?

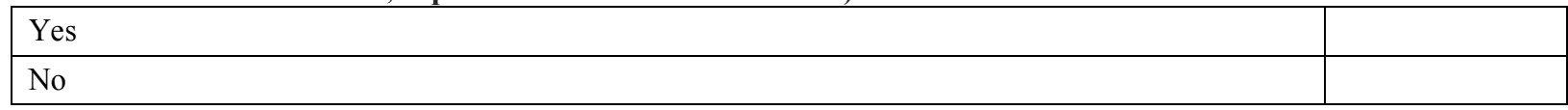

18. Where have you obtained information on your privacy rights in the past?

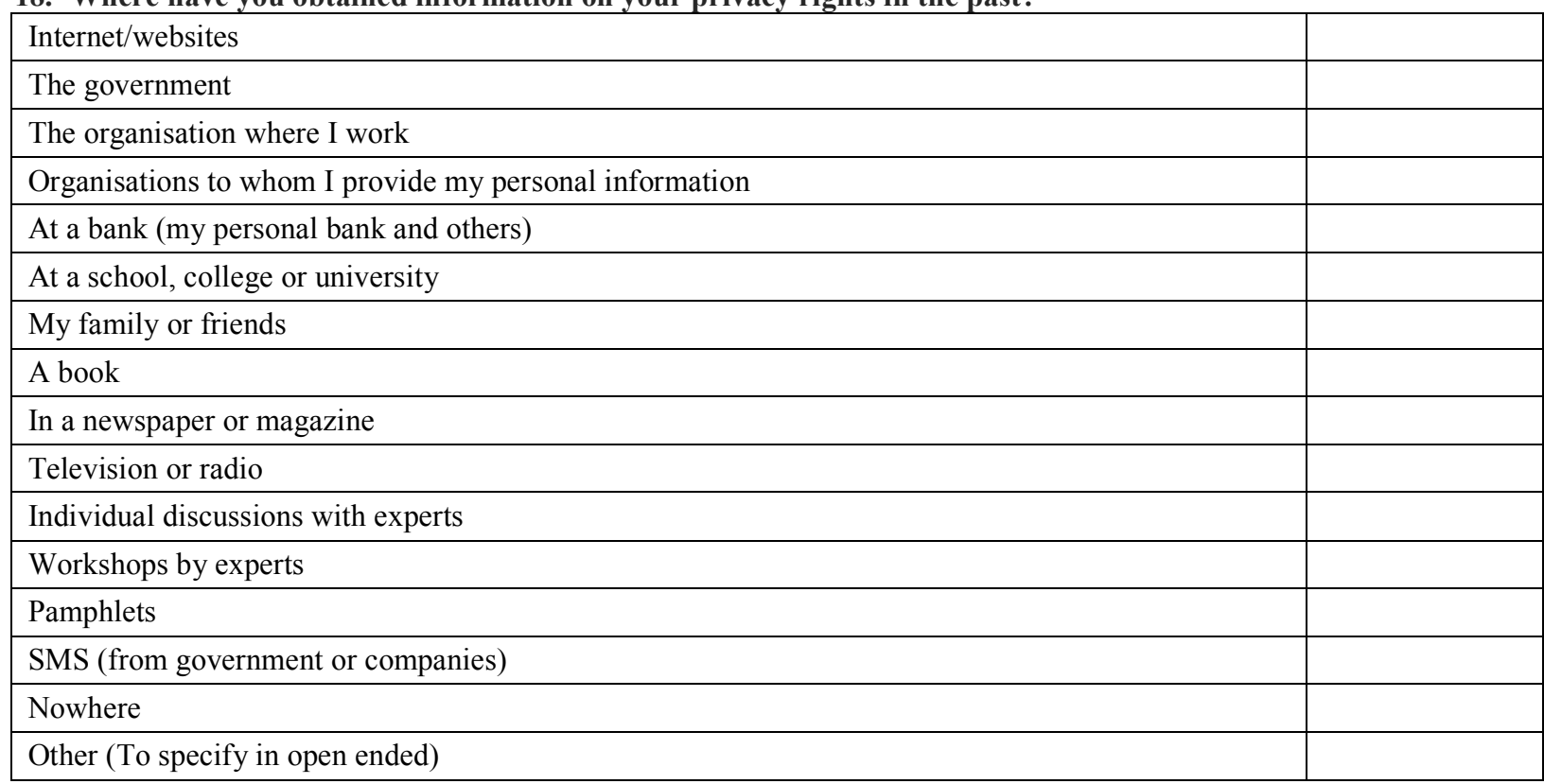


18b. Please specify where have you obtained information on your privacy rights in the past.

19. Which method(s) would you prefer to receive more information on your privacy rights?

Please rank your top 5 methods from the options below in order of preference, where $1=$ most preferred' and 5 = least preferred.

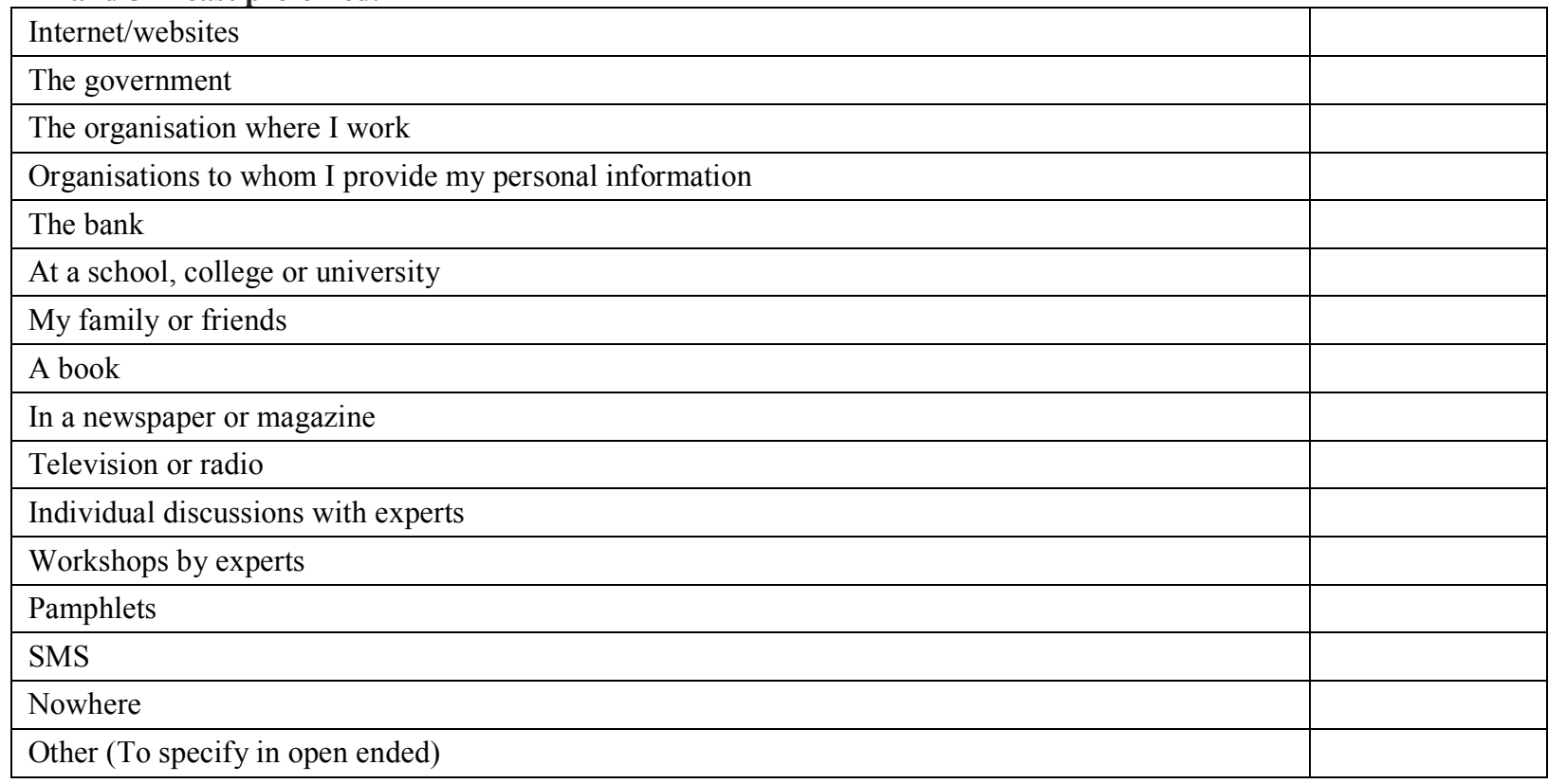

19b. Please specify which other method(s) would you prefer to receive more information on your privacy rights?

20. How concerned are you about the protection of your financial information?

\begin{tabular}{|l|l|}
\hline Not concerned & \\
\hline Somewhat concerned & \\
\hline Neutral & \\
\hline Concerned & \\
\hline Extremely concerned & \\
\hline
\end{tabular}

21. How concerned are you about the protection of your health information?

\begin{tabular}{|l|l|}
\hline Not concerned & \\
\hline Somewhat concerned & \\
\hline Neutral & \\
\hline Concerned & \\
\hline Extremely concerned & \\
\hline
\end{tabular}


22. How concerned are you about the protection of your identification information online (eg name, ID number etc)?

\begin{tabular}{|l|l|}
\hline Not concerned & \\
\hline Somewhat concerned & \\
\hline Neutral & \\
\hline Concerned & \\
\hline Extremely concerned & \\
\hline
\end{tabular}

23. Please indicate the extent to which you agree or disagree with the following statement:

“I know where to submit a complaint if I believe a company did not protect my personal information."

\begin{tabular}{|l|l|}
\hline Strongly disagree & \\
\hline Disagree & \\
\hline Neutral & \\
\hline Agree & \\
\hline Strongly agree & \\
\hline
\end{tabular}

\section{Section C: Privacy expectations}

In the following section, we would like to know more about your expectations from companies regarding their treatment of your personal information.

24. Please rate the extent to which you expect companies to handle your personal information in the various scenarios below:

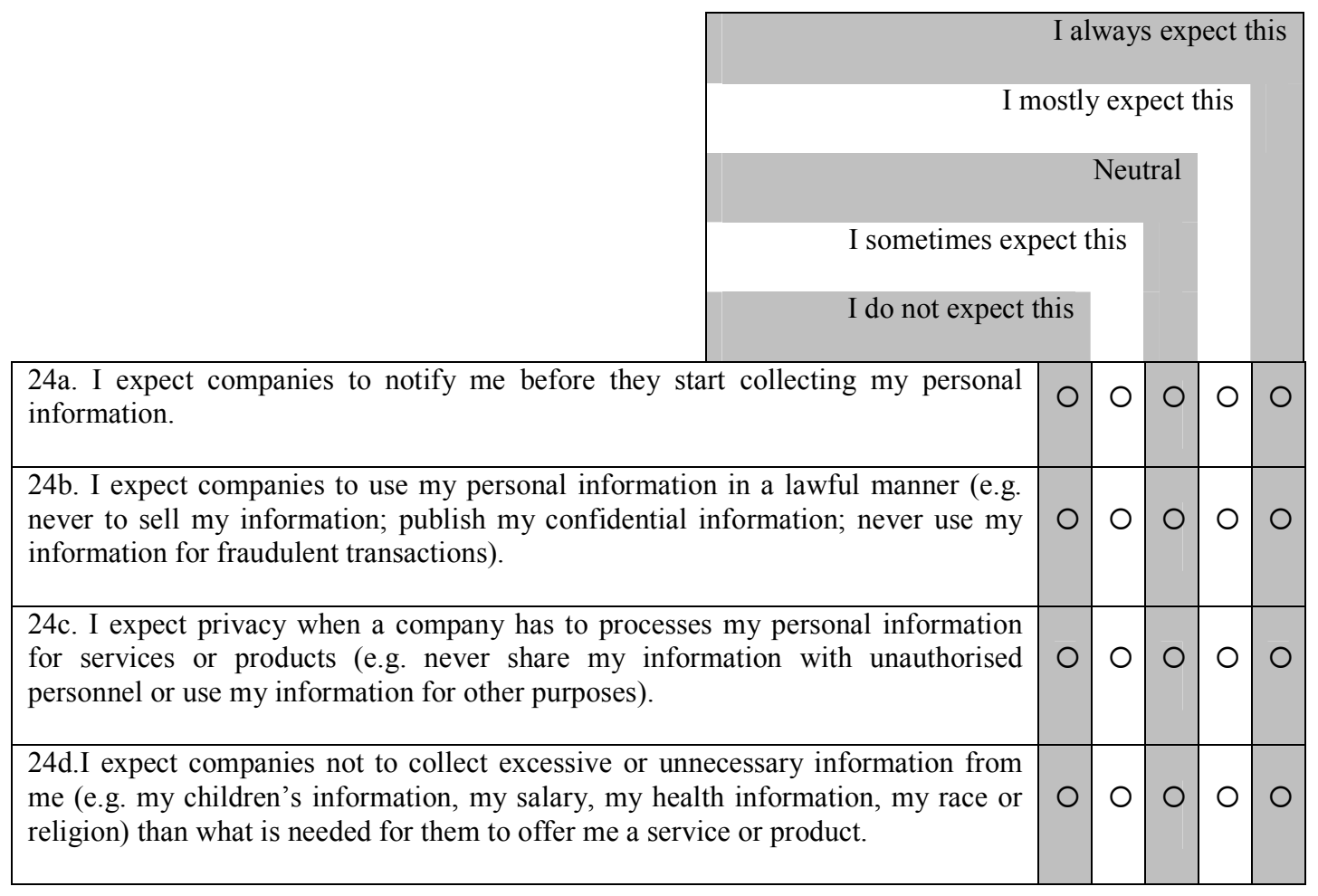




\begin{tabular}{|c|c|c|c|c|c|}
\hline $\begin{array}{l}\text { 24e.I expect companies to only collect my personal information when I have given } \\
\text { my consent; or if it is necessary for a legitimate business reason. }\end{array}$ & 0 & 0 & 0 & 0 & 0 \\
\hline $\begin{array}{l}\text { 24f. I expect companies to only collect my personal information from myself and } \\
\text { not from other sources (e.g. from other companies, people I know). }\end{array}$ & 0 & 0 & 0 & 0 & 0 \\
\hline $\begin{array}{l}24 \mathrm{~g} \text {. I expect companies to explicitly define the purpose for which they want to use } \\
\text { my information. }\end{array}$ & 0 & 0 & 0 & 0 & 0 \\
\hline $\begin{array}{l}\text { 24h. I expect companies to only use my personal information for purposes I agreed } \\
\text { to and never for other purposes (e.g. tele marketing, targeted advertising) than those } \\
\text { agreed by me. }\end{array}$ & 0 & 0 & 0 & 0 & 0 \\
\hline $\begin{array}{l}\text { 24i. I expect companies to only keep my personal information for as long as } \\
\text { required for business purposes or regulatory requirements. }\end{array}$ & 0 & 0 & 0 & 0 & 0 \\
\hline $\begin{array}{l}24 \mathrm{j} \text {. I expect companies to obtain my consent if they want to use my personal } \\
\text { information for purposes not agreed to with them. }\end{array}$ & 0 & 0 & 0 & 0 & 0 \\
\hline $\begin{array}{l}\text { 24k. I expect companies to inform me of the conditions (e.g. purposes, } \\
\text { consequences, recipients of my information, my rights and the way in which they } \\
\text { protect confidentiality) for processing my personal information. }\end{array}$ & 0 & 0 & 0 & 0 & 0 \\
\hline 241. I expect companies to keep my personal information updated. & 0 & 0 & 0 & 0 & 0 \\
\hline $24 \mathrm{~m}$. I expect companies to protect my personal information. & O & O & O & O & O \\
\hline $\begin{array}{l}24 n \text {. I expect companies to have all the necessary technology and processes in place } \\
\text { to protect my personal information. }\end{array}$ & O & O & O & O & O \\
\hline $\begin{array}{l}\text { 24o. I expect companies to ensure that their third parties (processing my personal } \\
\text { information) have all the necessary technology and processes in place to protect my } \\
\text { personal information. }\end{array}$ & O & O & O & O & O \\
\hline $\begin{array}{l}24 p \text {. I expect companies to inform me if records of my personal data were lost, } \\
\text { damaged or exposed publicly. }\end{array}$ & O & O & O & O & O \\
\hline $\begin{array}{l}\text { 24q. I expect companies to tell me what records of personal information they have } \\
\text { about me when I enquire about it. }\end{array}$ & $\mathrm{O}$ & $\mathrm{O}$ & O & $\mathrm{O}$ & O \\
\hline 24r. I expect companies to correct or delete my personal information at my request. & O & O & O & O & O \\
\hline $\begin{array}{l}\text { 24s. I expect companies not to collect sensitive personal information about me (e.g. } \\
\text { information on my children, religious beliefs, race or ethnic origin, trade union } \\
\text { membership, political persuasion, health or sex life, criminal record or biometric } \\
\text { information) }\end{array}$ & O & 0 & 0 & 0 & 0 \\
\hline $\begin{array}{l}\text { 24t. I expect companies to honour my choice if I decide not to receive direct } \\
\text { marketing. }\end{array}$ & 0 & 0 & 0 & 0 & 0 \\
\hline $\begin{array}{l}24 \mathrm{u} \text {. I expect companies to give me a choice if I want to receive direct marketing } \\
\text { from them. }\end{array}$ & 0 & 0 & 0 & 0 & 0 \\
\hline $\begin{array}{l}24 \mathrm{v} . \mathrm{I} \text { expect companies to protect my information when they have to send it to } \\
\text { other countries. }\end{array}$ & 0 & 0 & 0 & 0 & 0 \\
\hline
\end{tabular}



of your personal information.

25. Please rate the extent to which you are confident of companies' compliance with the law, when dealing with your personal information in various scenarios below:

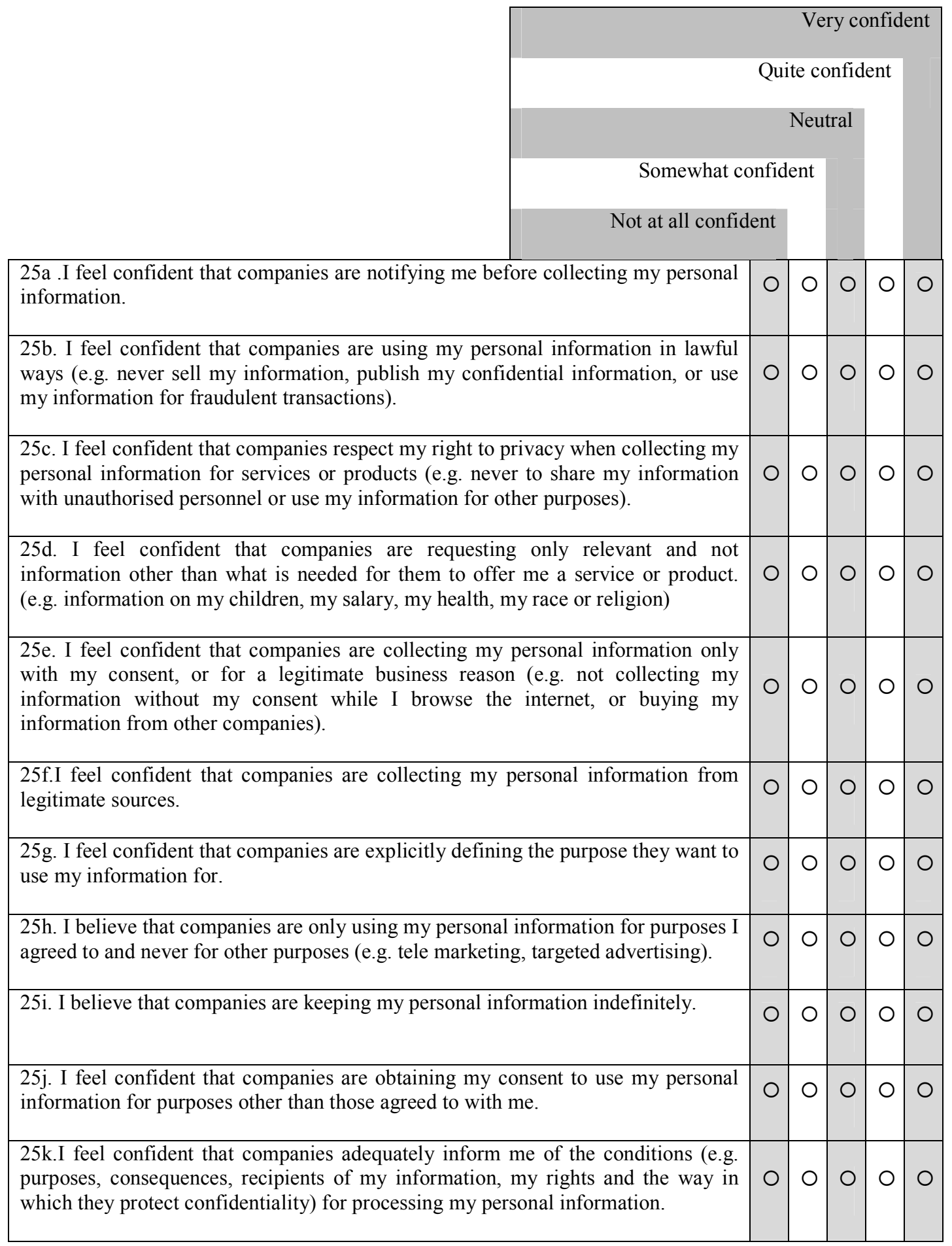




\begin{tabular}{|c|c|c|c|c|c|}
\hline 251. I feel confident that companies keep my personal information up to date. & O & O & O & O & O \\
\hline $\begin{array}{l}25 \mathrm{~m} \text {. I feel confident that companies are protecting my personal information (e.g. } \\
\text { keep my data confidential and protect it from being accessed by unauthorised } \\
\text { parties). }\end{array}$ & O & O & O & O & O \\
\hline $\begin{array}{l}25 \mathrm{n} \text {. I feel confident that companies have all the necessary technology and } \\
\text { processes in place to protect my personal information. }\end{array}$ & O & O & O & O & O \\
\hline $\begin{array}{l}\text { 25o. I feel confident that companies ensure that their third parties have all the } \\
\text { necessary technology and processes in place to protect my personal information. }\end{array}$ & O & O & O & O & O \\
\hline $\begin{array}{l}25 \mathrm{p} \text {. I feel confident that companies inform me if records of my personal data were } \\
\text { lost, damaged or exposed publicly. }\end{array}$ & O & O & O & O & 0 \\
\hline $\begin{array}{l}\text { 25q. I feel confident that companies can tell me what records or personal } \\
\text { information they have about me. }\end{array}$ & 0 & 0 & 0 & 0 & 0 \\
\hline $\begin{array}{l}25 \mathrm{r} \text {. I feel confident that companies will correct or delete my personal information } \\
\text { at my request. }\end{array}$ & 0 & 0 & 0 & 0 & 0 \\
\hline $\begin{array}{l}\text { 26s. I feel confident that companies only collect sensitive personal information (e.g. } \\
\text { information on my children, religious beliefs, race or ethnic origin, trade union } \\
\text { membership, political persuasion, health or sex life, criminal record or biometric } \\
\text { information) about me with my explicit consent. }\end{array}$ & 0 & 0 & 0 & 0 & 0 \\
\hline $\begin{array}{l}\text { 25t. I feel confident that companies honour my choice if I do not want to receive } \\
\text { direct marketing. }\end{array}$ & 0 & 0 & 0 & 0 & 0 \\
\hline $\begin{array}{l}25 \mathrm{u} \text {. Companies always give me a choice to indicate if I want to receive direct } \\
\text { marketing from them. }\end{array}$ & 0 & 0 & 0 & 0 & 0 \\
\hline $\begin{array}{l}25 \mathrm{v} \text {. I feel confident that companies protect my information if they have to send it } \\
\text { to other countries. }\end{array}$ & 0 & 0 & 0 & 0 & 0 \\
\hline $\begin{array}{l}25 \mathrm{w} \text {. I feel confident that if I submit a complaint it will be dealt with appropriately } \\
\text { by the relevant authorities. }\end{array}$ & 0 & 0 & 0 & 0 & 0 \\
\hline $\begin{array}{l}25 x \text {. I believe that organisations take their responsibility seriously to protect my } \\
\text { personal information. }\end{array}$ & 0 & 0 & 0 & 0 & 0 \\
\hline
\end{tabular}

Thank you for your participation. 